\title{
Bulk water charges in the dairy industry: A case study of interstate basins in Minas Gerais, Brazil
}

\section{Luiz Paulo de Lima ${ }^{*}$ (iD) Aline Gonçalves Spletozer $^{2}$ (D) Laércio Antônio Gonçalves Jacovine ${ }^{2}$ Antonio Fernandes de Carvalho ${ }^{3}$ iD}

'Eixo de Produção Alimentícia, Instituto Federal de Santa Catarina (IFSC), 89466-312, Canoinhas, SC, Brasil. E-mail: luiz.paulo@ifsc.edu.br. "Corresponding author.

${ }^{2}$ Departamento de Engenharia Florestal, Universidade Federal de Viçosa (UFV), Viçosa, MG, Brasil.

${ }^{3}$ Departamento de Tecnologia de Alimentos, Universidade Federal de Viçosa (UFV), Viçosa, MG, Brasil.

ABSTRACT: Water is an essential input for any agribusiness, used for various purposes such as hygiene procedures, heat exchangers and beverage formulation. Water charging, regulated in Brazil by the National Water Resources Policy (Federal Law 9.433/97), is an important issue for the food industry, since it may change the profile of food production costs. Thus, this article aimed to estimate the price increases in the dairy industry from the use of water charging and evaluate the potential benefit of this collection, comparing it to some planned investments in basins plans. We used a case study of a dairy that produced 1 t/d of mozzarella cheese in the state of Minas Gerais. Results indicated that water charging among the basins with current collection models may vary up to $131 \%$. The increase in price related to water charging was low (0.04-0.09\% of production costs), indicating that it can be absorbed by the industry. Conversely, values collected by the basins may be decisive for implementation of several actions aiming an average quantity and quality of water, which is good for the industry, itself. In the current charging collection models in the state of Minas Gerais, it is possible to recognize that collection is a promising initiative for the economical valuation of water. However, charging still seems to lack sufficiency in safety and a rationalization for its use.

Key words: dairy, national water resources policy, production costs, water pricing, water resources management.

Impacto da cobrança pelo uso da água bruta na indústria de laticínios: Um estudo de caso para bacias interestaduais no Estado de Minas Gerais

RESUMO: A água é um insumo essencial para qualquer agroindústria, utilizada para diversas finalidades, como em procedimentos de higienização, trocadores de calor e formulação de bebidas. Dessa forma, a cobrança pelo uso da água bruta, regulamentada no Brasil pela Politica Nacional de Recursos Hídricos - Lei $n^{\circ}$ 9.433/97 e leis estaduais, é um tema importante para a indústria de alimentos, uma vez que pode alterar o perfil dos custos de produção de bens alimentícios. Assim, este artigo objetivou estimar os incrementos de preço provenientes da cobrança pelo uso da água bruta em uma indústria de laticinios e avaliar o potencial benefício dessa arrecadação, comparando-a com alguns investimentos previstos em planos de bacias hidrográficas. Para tal, foi utilizado um estudo de caso de uma indústria de laticínios com produção de $1 \mathrm{t}$ /d de queijo mussarela, no Estado de Minas Gerais. Os resultados indicaram que o valor da cobrança pelo uso da água bruta entre as bacias hidrográficas com cobrança vigente pode variar em até $131 \%$. O incremento de preço obtido pela cobrança de uso da água bruta foi baixo (0,04-0,09\% dos custos de produção), indicando que este pode ser absorvido pelas indústrias. Por outro lado, os valores arrecadados pelas bacias podem ser decisivos para a efetivação de diversas ações voltadas para a melhoria da quantidade e da qualidade da água, beneficiando as próprias indústrias. Nos modelos de cobrança vigentes, no Estado de Minas Gerais, é possivel reconhecer que a cobrança é uma iniciativa promissora para valorar economicamente a água. Porém, a cobrança ainda parece ser insuficiente para assegurar a racionalização do seu uso.

Palavras-chave: custos de produção, gestão de recursos hídricos, laticínios, preço da água, política nacional de recursos hídricos.

\section{INTRODUCTION}

Water is an essential input for industries. In the dairy industry, water is used for purposes such as cleaning procedures, heat exchangers and brine preparation. Studies indicated that for each liter of milk processed, a dairy consumes from 1 to 7 liters of water (SILVA, 2006; SARAIVA et al., 2009; MAGANHA, 2006). However, due to the risk of scarcity, which plagues various areas of the country, this natural resource is transformed into an economic commodity (CORREA, 2016). An example of this was the creation of the National Water Resources Law (PNRH, in Portuguese), implemented by Federal Law No. 9,433/97 (BRASIL, 1997). Among 
other measures, the PNRH regulates a survey for raw water use.

The amount to be charged for the use of raw water is calculated based on a public price and aimed to: (i) indicate the actual value of water to its user; (ii) encourage its rational use; and (iii) obtain resources for basin recovery (BRASIL, 1997). Collection mechanisms and amounts are negotiated based on public debate within the Managing Committees of each basin (ANA, 2014); with the funds collected primarily applied in the basin in which they were generated (BRASIL, 1997). Currently, charging for water use follows the dominance of water between states and union, being present in both. The union has the domain of interstate basins, i.e., those that cover more than one state (Paraíba do Sul, Rio Doce, São Francisco, etc.), while the states have the domain of groundwater and rivers that are born and flow in the state itself (Médio Paraíba do Sul/Rio de Janeiro, Mogi/São Paulo, Piranga/Minas Gerais, etc.). Although, charging is present in both union and states-dominated basins, the charging practices are restricted to those basins that have implemented charging through the integrated action of their committee; thus, potential impacts are restricted to some basins in Brazil (ANA, 2018a; 2018b).

In general, the amount to be charged for the use of raw water is a function of the volume $\left(\mathrm{m}^{3}\right)$ of surface and/or groundwater extraction, water consumption (difference between the volume captured and released), and the discharge of effluents (with charge according to organic load, measured in $\mathrm{kg}$ of biochemical oxygen demand (BOD)). However, not all basins adopt this charge. Furthermore, among the basins that charge for raw water use, there are variations between charging mechanisms (e.g., unit values for each type of use). Therefore, depending on the geographical location of the dairy, and despite the fact that it may have the same production profile as other dairies, it may pay different amounts for raw water use, or even it may not have any charge.

This scenario is complex because one of the main consequences of charging this public price is the increase in production costs. This, in turn, will lead to lower profit margins and/or higher prices for consumers. Consequently, the location of the dairy can be a determining factor for its competitiveness, contributing to its permanence (or not) in the market.

Small number of studies related to industrial water use (FÉRES et al., 2005) and the impact of charging for its use (OCDE, 2017), makes it difficult to deepen these discussions, especially for a specific sector such as the dairy industry. Therefore, it is necessary to document the impacts of this charge on competitiveness among industries and, at the same time, to consider the economic benefit of charging for the use of water resources for their management (OCDE, 2017). Thus, this article aimed to estimate the price increases resulting from raw-water use charges through a case study of a dairy producing mozzarella cheese, and to evaluate the potential benefit of this collection, comparing it with some planned investments in basins plans.

\section{MATERIALS AND METHODS}

This research was conducted from a case study of a small dairy located in Minas Gerais, producing $1 \mathrm{t} / \mathrm{d}$ of mozzarella cheese $(360 \mathrm{~d} /$ year). Mozzarella cheese is the most consumed cheese in Brazil (SEBRAE, 2014). In 2011, Brazil produced about $8.67 \times 10^{5} \mathrm{t}$ of cheese, of which $28.1 \%$ (equivalent to $2.44 \times 10^{5} \mathrm{t}$ ) was mozzarella cheese (SEBRAE, 2014). The state of Minas Gerais has the largest concentration of dairies (LIMA et al., 2017) and is the largest dairy producer in the country (IBGE, 2018).

Impact of raw water charges on the dairy industry was assessed by: (i) identifying the current raw water charge models in Minas Gerais; (ii) calculating the respective amounts to be charged/collected by the basin water agencies for the use of raw water by the dairy industry; (iii) estimating possible increases in the cost of cheese production associated with the charge for the use of raw water; and (iv) measuring the representativeness of the annual amount collected by the water agencies for the dairy's raw water use as compared to the amount required for the execution of some investments in the basin.

\section{Current evaluation models}

Data referring to models for charging for the use of raw water in basins were collected from the information available on the website of the National Water Agency (ANA, in Portuguese). Models for charging for the use of raw water for each installment (capture, consumption, release and transposition) follow the calculation structure:

Amount charged $=$ (Basis of calculation). (Unit price). (Coefficients)

where Amount charged is the financial value of each installment (capture, consumption, release or transposition) corresponding to the charge for the use of water resources; Basis of calculation refers to the volume of water used for extraction, consumption, release (and/or dilution), 
or transposition; Unit price defines the unit financial value per $\mathrm{m}^{3}$ of water use, based on the objectives of the collection instrument; and, the Coefficients aimed to adapt the defined mechanisms to objectives, specificities of the basin or specific uses. Coefficients may vary, depending on the objectives, the classes of water body use at the capture and release points (or generally, interference points in the water body).

Total amount to be charged is the result of the sum of the amounts charged in each of the parcels, referring to the different types of water use. It should be noted that, depending on the type of water use or the basin, the calculation structure described may have different unit public prices and coefficients.

\section{Amounts charged}

The amounts to be charged were calculated from the unit prices and the current collection coefficients in the interstate basins, with collection implemented in Minas Gerais (Table 1). For the calculations, we considered: (i) water consumption (1.51 L of water per L of processed milk), effluent generation $(58.86 \mathrm{~kg}$ of chemical oxygen demand ratio-COD per $\mathrm{m}^{3}$ of processed milk), and BOD/ COD ratio (0.29), available from SILVA (2006); (ii) yield (9.9 L of milk for each $\mathrm{kg}$ of cheese produced with acidified dough after $24 \mathrm{~h}$ in refrigeration), available from MENDES et al. (2015); (iii) effluent uptake/discharge in Class 2 water body, with water reuse rate between $0-20 \%$; and (iv) discharge of effluents with a $70 \%$ BOD removal rate.

\section{Price increment}

The estimate of the price increase for mozzarella cheese associated with the charge for the use of raw water was made through the relationship between the amount charged for the use of raw water and the sale price of cheese in the industry for each basin. The selling price of cheese in the industry was estimated from the price average of mozzarella cheese in retail in the state of São Paulo in 2017 (CEPEA, 2017; 2018), and data on the distribution of profit margin to the production chain dairy products (MILKPOINT, 2016). We used data for São Paulo as a function of the availability of a monthly database. The state is also a major consumer center. Throughout 2017, the sale price of $1 \mathrm{~kg}$ of mozzarella cheese in the state ranged from $R \$ 14.11$ to $R \$ 15.82$, with an average of R\$ 14.88 (CEPPEA, 2017; 2018).

\section{Charging representativity}

Finally, we analyzed the percentage ratio between the annual estimates of the amount collected through charging for raw water at the dairy in question, and the amount needed to make some investments to improve quantity and quality of water from a basin.

\section{RESULTS AND DISCUSSION}

\section{Current evaluation models}

In addition to the São Francisco basin, in which most of the mining territory is located, charging for the use of raw water is implemented in the following interstate basins: Paraíba do Sul, Piracicaba/Jaguari, Doce and Paranaíba. States basins with implemented charges are: Araguari, Caratinga, Manhuaçu, Pará, Piracicaba, Piracicaba and Jaguari, Piranga, Pomba and Muriaé, Preto/Paraibuna, Santo Antonio, Suaçuí and Velhas (ANA, 2018b). Due to the diversity of charging models in use in the state basins of Minas Gerais (ANA, 2018b), for calculation purposes, only the interstate basins under the domain of the union were considered. The choice is due to their greater territorial coverage of the state when compared to state basins. Figure 1 illustrates the spatial organization of interstate basins of Minas Gerais.

\section{Amounts charged \\ Unitary public prices presented for models of raw-water use charges from interstate}

Table 1 - Unit public prices (PPU) charged for raw-water use in interstate basins covering Minas Gerais.

\begin{tabular}{|c|c|c|c|c|c|c|}
\hline Use & Unit & Doce & Paraíba do Sul & Paranaíba & Piracicaba/Jaguari & São Francisco \\
\hline Catchment & $\mathrm{R} \$ / \mathrm{m}^{3}$ & 0.0308 & 0.0112 & 0.0152 & 0.0130 & 0.0103 \\
\hline Consumption & $\mathrm{R} \$ / \mathrm{m}^{3}$ & * & 0.0224 & * & 0.0262 & 0.0205 \\
\hline Wastewater release & $\mathrm{R} \$ / \mathrm{kg}^{* *}$ & 0.1643 & 0.0784 & 0.0709 & 0.1308 & 0.0719 \\
\hline Transposition & $\mathrm{R} \$ / \mathrm{m}^{3}$ & 0.0411 & $*$ & $*$ & 0.0196 & $*$ \\
\hline
\end{tabular}

*unreported charge amounts; ${ }^{* *}$ measured in $\mathrm{kg}$ BOD.

Source: ANA (2018b). 


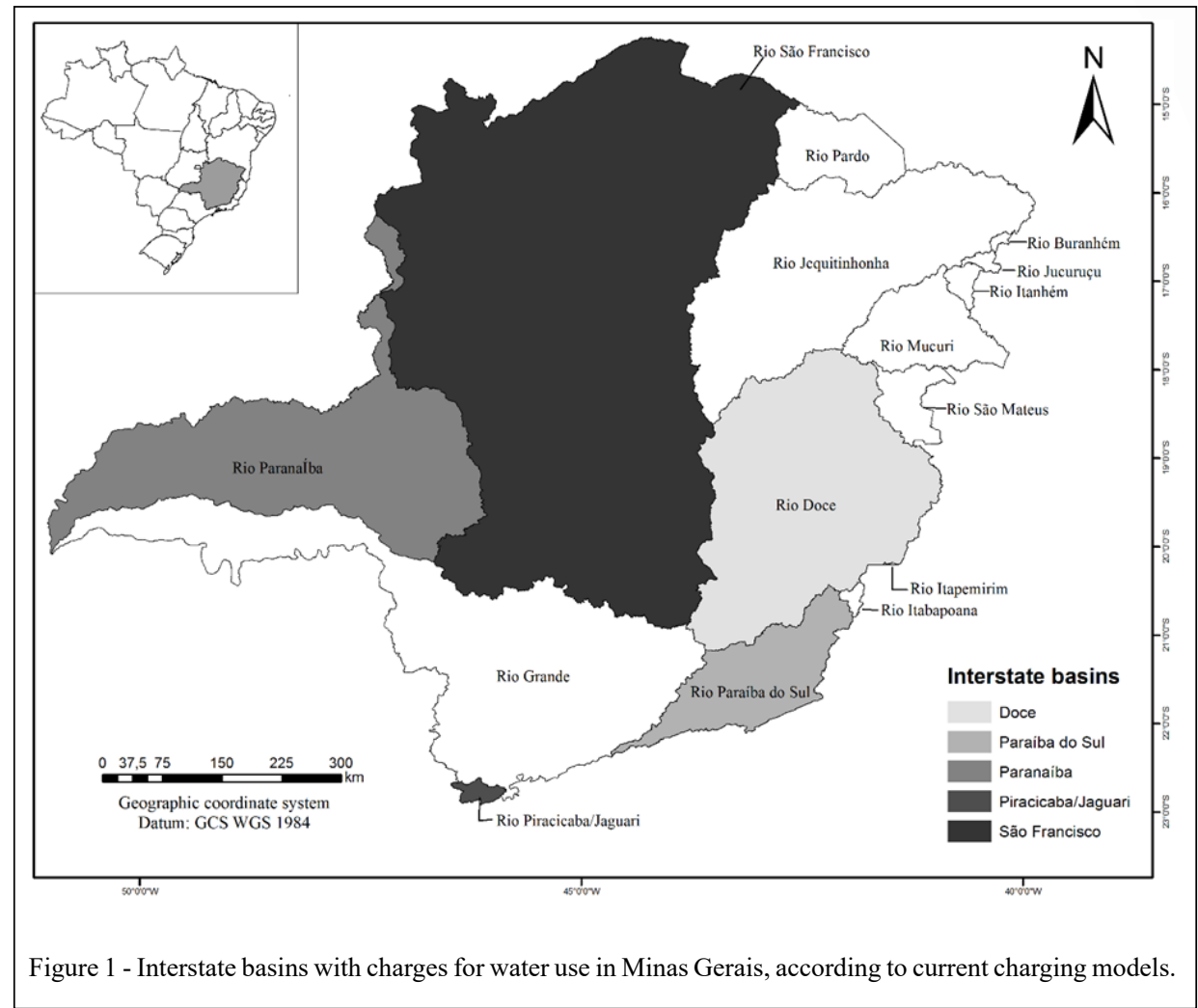

basins covering Minas Gerais are detailed in table 1. These values refer to the 2018 fiscal year, specified in Resolution No. 20 (ANA, 2018b). According to the data presented, it can be verified that all basins are charged for raw water extraction and effluent discharge (organic load, measured in $\mathrm{kg}$ BOD). The same is not true for the consumption and transposition of water. The amounts charged for discharging effluents are 366-906\% higher than those charged for raw water extraction. The Rio Doce basin registers the highest collection amounts for raw water extraction $\left(\mathrm{R} \$ 0.0308 / \mathrm{m}^{3}\right)$ and for the discharge of effluents ( $\mathrm{R} \$ 0.1643 / \mathrm{kg})$.

\section{Price increment}

Results obtained in relation to the rawwater use charge for the dairy evaluated are presented in table 2. The Rio Doce basin presented the highest currency amount collected for raw water use (R\$ $3,164.33$ year), equivalent to $\mathrm{R} \$ 0.01$ per $\mathrm{kg}$ of mozzarella cheese $-0.09 \%$ of the average selling price of the product in the industry. For the other basins, the annual amount charged for the use of raw water ranges from $\mathrm{R} \$ 1,367.65$ to $\mathrm{R} \$ 2,457.14$, representing 0.04 $0.07 \%$ of the cheese sales price in the industry.
Results showed that the increase in the production cost of the mozzarella cheese, and consequent price increase caused by the raw water charge, is low. That is, these costs can be absorbed by the dairies. These costs of water input in the production of mozzarella cheese are below those obtained by other authors. FÉRES et al. (2005) reported a water input cost in relation to the sale price of $0.28 \%$ in the food and beverage industries located in the Paraíba do Sul basin.

\section{Charging representativity}

The amounts charged for raw water use appear to be unrepresentative for the dairies. However, the amounts collected by the basin committees can be decisive for the implementation of various actions aimed at improving the quantity and quality of water. Table 3 illustrates the relationship between the annual amount paid by the dairy industry and the amount needed to make some investments to improve water quantity and quality. In this case, the representativeness of the amounts paid was estimated, considering the charging models in force in each of the interstate basins, and an interval was presented, referring to the percentage of what was collected from 
Table 2 - Annual charge for the use of raw water (R\$), corresponding to the production of mozzarella cheese, for surface catchment and wastewater discharge in the assessed dairy industry, by basin*.

\begin{tabular}{|c|c|c|c|c|c|}
\hline Use & Doce & Paraíba do Sul & Paranaíba & Piracicaba/Jaguari & São Francisco \\
\hline Surface catchment & 165.75 & 60.27 & 81.80 & 69.96 & 55.43 \\
\hline Wastewater release & $2,998.57$ & $1,430.85$ & $1,293.97$ & $2,387.18$ & $1,312.22$ \\
\hline Total annual value & $3,164.33$ & $1,491.12$ & $1,375.77$ & $2,457.14$ & $1,367.65$ \\
\hline Value per kg of mozzarella cheese & 0.00879 & 0.00414 & 0.00382 & 0.00683 & 0.00380 \\
\hline
\end{tabular}

* considering the capture and discharge of wastewater for industrial use in Class 2 water bodies, with a water reuse rate between $0-20 \%$. For calculation purposes, we considered the annual volume of water captured, in $\mathrm{m}^{3} / \mathrm{year}$, according to grant values, equal to the annual volume of water captured, in $\mathrm{m}^{3} /$ year, according to measurement data.

the evaluated dairy, compared to the values required for the implementation of investments.

Even analyzing the charge for raw water use at a small dairy, as in the present study, the total amount paid over a year is relevant for a basin. By itself, charging for the use of raw water needed for the annual production of this dairy corresponds, for example, to the price of recovering $0.27-0.63$ ha of springs and riparian forests, or recovering $0.37-0.86$ ha of eroded land, according to the values specified in the Executive Summary of the Alto Rio Grande Basin Water Resources Master Plan (IGAM, 2014). Thus, when considering a larger dairy or a set of enterprises that pay for the use of raw water, it is expected that a larger volume of resources will be raised, enabling greater investments, such as the implementation of landfill units, selective collection and wastewater treatment.

Investing the resources raised in the basin itself is beneficial for industries, as it can contribute to maintaining, improving and increasing the quality and volume of the water supply. These resources allow more sustainable management of local water resources, avoiding, for example, water scarcity scenarios. It should be noted that, in times of water crisis, a reduction or prohibition of some uses of water (e.g., industrial), to the detriment of human consumption, is foreseeable. In addition, water resources management must always provide for multiple water uses (BRASIL, 1997), which reinforces the commitment that industries must make to reducing the risk of scarcity.

Charging for the use of raw water is in accordance with the National Environmental Policy (BRASIL, 1981), which imposes on users a requirement to contribute to the use of environmental resources for economic purposes, and imposes on the polluter, from the viewpoint of dilution of wastewater in water bodies, the obligation to recover and/or indemnify the damage caused. Thus, this mechanism aimed to recognize the economic value of water by charging for its use, and finances programs for the environmental recovery of water resources, since the

Table 3 - Relationship between the total amount paid for raw water use in the Alto Rio Grande Basin and the average value of some investments aimed to improve water quantity and quality.

\begin{tabular}{lcc}
\hline Investment & ${\text { Average value }{ }^{*}(\mathrm{R} \$)}$ & Ratio (\%) $^{* *}$ \\
\hline Landfill (unit) & $411,688.13$ & $0.33-0.77$ \\
Selective collection (unit) & $50,000.00$ & $2.74-6.33$ \\
Recovery of springs and riparian forests (ha) & $5,025.48$ & $27.21-62.97$ \\
Recovery of eroded land (ha) & $3,683.45$ & $37.13-85.91$ \\
Flood prediction and warning system (unit) & $157,500.00$ & $0.87-2.01$ \\
Sanitary sewage treatment (unit) & $2,530,187.70$ & $0.05-0.13$ \\
Sorting ecomposting (unit) & $250,000.00$ & $0.55-1.27$ \\
\hline
\end{tabular}

*in accordance with the investments foreseen in the Alto Rio Grande Basin Water Resources Master Plan between 2015 and 2034 (IGAM, 2014); ${ }^{* *}$ refers to the estimates of the total collected by the studied basins, regarding the charge for. 
resources received are used to improve the quantity and quality of water in the basin itself. However, the effectiveness of charging for the use of raw water in relation to the incentive to rationalize its use has yet to be proven. This involves the collection of values that allows reduction of pollution to a value that respects the framing of water bodies, which defines the quality required for water and its preponderant uses. FÉRES et al. (2005) and FLORES et al. (2010), for example, demonstrated that the cost of wastewater treatment is much higher than charging for its dilution. In FLORES et al. (2011), for example, charging for the use of raw water represented $2.14 \%$ of the cost for its wastewater treatment in concentrated milk production.

Implementing charges for the use of raw water with relatively low values may be a strategy to achieve greater acceptance in a production environment and thus facilitate the implementation of this type of policy. However, 15 years after the application of charges for the use of raw water in federal basins in Brazil (ANA, 2018a), it is necessary to update the amounts charged to bring them closer to the real value of this natural resource. Thus, industries would be encouraged to use it rationally, just as they do with other resources (e.g., energy and raw materials). Admittedly, further studies are needed to understand the broader impact of raw water charges on all facets of the dairy industry. Depending on the added value of the product and the production profile (wastewater treatment, extraction and water consumption) this impact may be more (or less) significant than those obtained in this research. Moreover, Brazil's dairy industry is quite diverse, producing similar products through different technologies.

The choice of Minas Gerais was due to its representativeness for the dairy sector (LIMA et al., 2017; IBGE, 2018), while the choice of interstate basins was due to its coverage (Figure 1). However, the extrapolation of the results of this research to other states and/or basins should be carefully analyzed, since not all models of raw-water charges in Brazil were reviewed. Similarly, it should be noted that, depending on the technological level (production methods) and the market strategy (selling price) adopted, there may be considerable differences in the impact of charging for the use of raw water, compared to that identified for the dairy industry in question.

\section{CONCLUSION}

The amount to be paid for the use of raw water in the production of mozzarella cheese in federal basins in Minas Gerais varies depending on the current charging models, and the highest amount charged is slightly more than double the lowest value. Relationship between the amount charged for raw water use in the assessed dairy and the selling price of the product in the industry ranged from $0.04-0.09 \%$, indicating that the value charged for the use of raw water used in the production of mozzarella cheese is too low.

From current charging models, it is possible to recognize that charging is a promising initiative to economically value water. And, through the collected amounts, it is possible to finance actions for environmental recovery of water resources. Due to the low impact of the raw water charge on the final price of mozzarella, the amounts charged do not yet induce rationalization, since there are reports in the literature that the raw water charge is still much lower than the costs involved with wastewater treatment and/or its reuse in other production processes (FÉRES et al., 2005; FLORES et al., 2010).

\section{ACKNOWLEDGEMENTS}

To Coordenação de Aperfeiçoamento de Pessoal de Nível Superior (CAPES) - Financing Code 001, for supporting the L.P.L. and A.G.S. with postgraduate fellowship. To the industry that supplied the data and the Universidade Federal de Viçosa.

\section{DECLARATION OF CONFLICT OF INTERESTS}

The authors declare no conflict of interest. The founding sponsors had no role in the design of the study; in the collection, analyses, or interpretation of data; in the writing of the manuscript, and in the decision to publish the results.

\section{AUTHORS' CONTRIBUTIONS}

The authors contributed equally to the manuscript.

\section{REFERENCES}

AGÊNCIA NACIONAL DE ÁGUAS (ANA). Cobrança pelo uso de recursos hídricos. Agência Nacional de Águas, Brasília: ANA, 2014. 80p. Available from: <http:// arquivos.ana.gov.br/institucional/sge/CEDOC/Catalogo/2014/ CadernosdeCapacitacaoemRecursosHidricosVol7.pdf $>$. Accessed: Aug. 23, 2019.

AGÊNCIA NACIONAL DE ÁGUAS (ANA). Conjuntura dos recursos hídricos no Brasil 2018:informe anual / Agência Nacional de Águas. Brasília: ANA, 2018a.72p. Available from: $<$ http://arquivos.ana.gov.br/portal/publicacao/Conjuntura2018. pdf $>$. Accessed: Aug. 23, 2019.

AGÊNCIA NACIONAL DE ÁGUAS (ANA). Normativos da Cobrança. 2018b. Available from: <http://www3.ana.gov.br/ portal/ANA/gestao-da-agua/cobranca/normativos-cobranca>. Accessed: Aug. 17, 2018. 
BRASIL. Lei no 6.938, de 31 de agosto de 1981. Dispõe sobre a Política Nacional do Meio Ambiente, seus fins e mecanismos de formulação e aplicação, e dá outras providências. Available from: <http://www.planalto.gov.br/ccivil_03/leis/L6938.htm>. Accessed: Jul. 11, 2018.

BRASIL. Lei $\mathrm{n}^{\circ}$ 9.433, de 8 de janeiro de 1997. Institui a Política Nacional de Recursos Hídricos, cria o Sistema Nacional de Gerenciamento de Recursos Hídricos. Available from: <http:/ www.planalto.gov.br/ccivil_03/Leis/L9433.htm>. Accessed: Jul. 11,2018

CENTRO DE ESTUDOS AVANÇADOS EM ECONOMIA APLICADA - ESALQ/USP (CEPEA). Boletim do Leite. São Paulo: ESALQ/USP, n.260-271, 2017. Available from: <https:// www.cepea.esalq.usp.br/br/categoria/boletim-do-leite.aspx $>$. Accessed: Aug. 23, 2019

CENTRO DE ESTUDOS AVANÇADOS EM ECONOMIA APLICADA - ESALQ/USP (CEPEA). Boletim do Leite. São Paulo: ESALQ/USP, n.272, 2018. Available from: $<$ https://www. cepea.esalq.usp.br/br/categoria/boletim-do-leite.aspx $>$. Accessed: Aug. 23, 2019

CORREA, P.S.G. Water as environmental resource: the collection based on the principle of user-payer. Planeta Amazônia, n.8, p.1-13, 2016. Available from: <http://dx.doi.org/10.18468/ planetaamazonia.2016n8.p01-13>. Accessed: Jul. 11, 2018. doi: 10.18468/planetaamazonia.2016n8.p01-13.

FÉRES, J. et al. Demanda por água e custo de controle da poluição hídrica nas indústrias da bacia do rio Paraíba do Sul. Texto para discussão $\mathrm{n}^{\circ}$ 1084. Ipea: Rio de Janeiro, 2005. 62p. Available from: <http://www.ipea.gov.br/portal/images/stories/ PDFs/TDs/td 1084.pdf >. Accessed: Jul. 11, 2018.

FLORES, A.F. et al. Identificação da Demanda de Água na Produção de Leite Concentrado, na Indústria CONFEPAR AgroIndustrial Cooperativa Central, Unidadede Pato Branco-PR: Um estudo de caso. Synergismus scyentifica UTFPR, v.6, n.1, 2011. 6p. Available from: <http://revistas.utfpr.edu.br/pb/index.php/ SysScy/article/download/1306/847>. Accessed: Jul. 11, 2018.

INSTITUTO BRASILEIRO DE GEOGRAFIA E ESTATÍSTICA (IBGE). Pesquisa Pecuária Municipal. Available from: <https:// sidra.ibge.gov.br/tabela/74>. Accessed: Jul. 11, 2018.

INSTITUTO MINEIRO DE GESTÃO DAS ÁGUAS (IGAM). Resumo Executivodo Plano Diretor de Recursos Hídricos da
Bacia do Alto Rio Grande. Consórcio Ecoplan-Lume- Skill. BeloHorizonte: IGAM, 2014. 57p. Available from: < http://www. reunioes.semad.mg.gov.br/down.asp?x_caminho=reunioes/ sistema/arquivos/material/\&x_nome=Item_5.1_-_Resumo_Exec. da_Prop._Enquadramento_GD1.pdf $>$. Accessed: Aug. 23, 2019.

LIMA, L.P. et al. The dairy industry in Brazil-An exploratory study. Boletim do Centro de Pesquisa e Processamento de Alimentos, v.35, 2017. p.13. Available from: <http://dx.doi. org/10.5380/cep.v35i1.55942>. Accessed: Jul. 11, 2018. doi: 10.5380/cep.v35i1.55942.

MAGANHA, M.F.B. Guia técnico ambiental da indústria de produtos lácteos. São Paulo: CETESB, 2006. 95p. Available from: $<$ http://www.cetesb.sp.gov.br>. Accessed: Jan. 01, 2015.

MENDES, B.G. et al. Quality and performance of musssarela in times ofacidified mass under refrigerated storage. Revista Brasileira de Tecnologia Agroindustrial, v.9, n.1, p.1744-1756, 2015. Available from: <http://dx.doi.org/10.3895/rbta.v9n1.1898> Accessed: Jul. 11, 2018. doi: 10.3895/rbta.v9n1.1898.

MILKPOINT. Não é o R\$ 1,5/litro ao produtor... 2016. Available from: <https://www.milkpoint.com.br/cadeia-doleite/panorama/nao-e-o-r-15litro-ao-produtor-98892n.aspx $>$. Accessed: Jul. 11, 2018.

ORGANIZAÇÃO PARA A COOPERAÇÃO E DESENVOLVIMENTO ECONÔMICO (OCDE). Cobranças pelo uso de recursos hídricos no Brasil: Caminhos a seguir. Éditions OCDE, Paris. 2017. Available from: <http://dx.doi. org/10.1787/9789264288423-pt>. Accessed: May, 10, 2019.

SARAIVA, C.B. et al. Water consumption and effluent generation in a small dairy industry. Revista Instituto de Laticínios Cândido Tostes, n.367-368, v.64, p.10-18, 2009. Available from: $<$ https://www. revistadoilct.com.br/rilct/article/view/75/81>. Accessed: Jul. 11, 2018.

SERVIÇO BRASILEIRO DE APOIO ÀS MICRO E PEQUENAS EMPRESAS (SEBRAE). Técnicas e boas práticas na produção de queijo. 2014. 6p. Available from: $<$ http://www.sebraemercados. com.br/wp-content/uploads/2015/12/2014_02_27_RT_Agron_ QueijoIN30_pdf.pdf $>$. Accessed: Jul. 11, $201 \overline{18}$.

SILVA, D.J.P. Diagnoses of water consumption and generation of effluents in a dairy industry and development of a support multimedia system. 2006. 100f. Dissertação (Mestrado em Ciência e Tecnologia de Alimentos) - Curso de Pós-Graduação em Ciência e Tecnologia de Alimentos, Universidade Federal de Viçosa. 